\title{
PENERAPAN PRINSIP PROFIT SHARING DAN REVENUE SHARING PROGRAM TABUNGAN MUDHARABAH DAN DEPOSITO MUDHARABAH (STUDI PADA PT BANK MUAMALAT KANTOR CABANG MAKASSAR)
}

\author{
Wika Ramdhani Hafid \\ Universitas Islam Negeri Alauddin Makassar \\ wikaramdhanihafid@gmail.com \\ Jamaluddin Majid \\ Universitas Islam Negeri Alauddin Makassar \\ jamal.majid@uin-alauddin.ac.id \\ Muh. Sapril Sardi Juardi \\ Universitas Islam Negeri Alauddin Makassar \\ sapril.sardi@uin-alauddin.ac.id
}

\section{Keywords: \\ Islamic bank, profit \\ sharing, savings \\ Mudharabah, \\ Mudharabah deposits and \\ profit sharing.}

\section{Kata Kunci:}

Bank Syariah, Bagi

Hasil, Tabungan

Mudharabah, Deposito

Mudharabah, dan Profit

Sharing.

\section{ABSTRACT}

This study aims to determine the application of the system to result in a savings program mudaraba and deposits mudaraba there are at PT Bank. Muamalat KC Makassar. In addition, this study also aimed to determine the application sharing system in PT Bank Muamalat KC Makassar related to accountability and good kemaslahatannya it to shabibul maal or mudharib. The data collection method is the research field(FieldResearch), interviews with informants, literature and internet searching. The results of this study showed that the distribution of the revenue share in PT Bank. Muamalat KC Makassar using the principle of profit sharing for the distribution of profit sharing program Mudharabah savings and deposits of mudaraba done by dividing the bank's net income after deducting the costs incurred pengelolah funds. Meanwhile, related to the welfare of the two principles of distribution of profit sharing, profit sharing is considered the most serious benefits between the two parties defense.

\begin{tabular}{l}
\hline ABSTRAK \\
\hline Penelitian ini bertujuan untuk mengetahui penerapan sistem bagi \\
hasil pada program tabungan mudharabah dan deposito \\
mudharabah yang ada pada PT Bank Muamalat KC Makassar. \\
Selain itu, penelitian ini juga bertujuan untuk mengetahui penerapan \\
sistem bagi hasil di PT Bank Muamalat KC Makassar terkait \\
dengan akuntabilitas dan kemaslahatannya baik itu untuk shabibul \\
maal maupun mudharib. Metode pengambilan data yaitu penelitian \\
lapangan (Field Research), wawancara langsung dengan informan, \\
studi pustaka dan internet searching. Hasil penelitian ini diperoleh \\
bahwa pendistribusian bagi hasil pada PT Bank Muamalat KC \\
Makassar menggunakan prinsip profit sharing karena pendistribusian \\
bagi hasil program tabungan mudharabah dan deposito \\
mudharabah dilakukan dengan membagi pendapatan bersih bank \\
setelah dikurangi biaya yang dikeluarkan pengelolah dana. \\
Sedangkan terkait dengan kemaslahatan antara kedua prinsip \\
pendistribusian bagi hasil, profit sharing dianggap paling maslahat \\
antara kedua bela pihak.
\end{tabular}




\section{PENDAHULUAN}

Perbankan Syariah dikenal sebagai Islamic Banking yang pada awalnya dikembangkan sebagai suatu respon dari kelompok ekonomi dan praktisi yang berlingkup syariah. Sejak adanya revisi UU No. 10 Tahun 1998 tentang perbankan terdapat beberapa perubahanyang memberikan peluang yang lebih besar bagi pengembangan perbankan syariah. Dari UU tersebut menerangkan bahwa sistem perbankan syariah dikembangkan dengan beberapa tujuan yakni memenuhi kebutuhan jasa perbankan bagi masyarakat yang tidak menerima konsep bunga, memenuhi kebutuhan akan produk dan jasa perbankan yang memiliki beberapa keunggulan komparatif berupa peniadaan pembebanan bunga, membuka peluangpembiayaan bagi pengembangan usahaberdasarkan prinsip kemitraan dengan menjaga hubungan investoryang harmonis. Sementara pada bank konvensional konsep yang diterapkan adalah hubungan debitur dan kreditur.

Denganadanya hal-hal tersebut banyak menimbulkan kekhawatiran bagi bank-bank konvensional, sehingga sekarang banyak bank konvensional yang membuka unit syariah. Perbankan syariah berusaha mengakomodir berbagai pihak yang menginginkan adanya jasa transaksi keuangan yang berjalan sesuai dengan prinsip-prinsip syariah, agar terhindar dari pelanggaran praktek riba, kegiatan yang sifatnya serupa dengan perjudian, gharar (ketidakpastian), dan pelanggaran prinsip dalam transaksi. Kemunculan bank syariah merupakan upaya gencar yang dilakukan oleh para pakar islam dalam mendukung ekonomi islam yang diyakini akan mampu mengganti dan memperbaiki sistem ekonomi konvensional yang berbasis pada bunga (Supono, 2010:3).

Pertumbuhan ekonomi yang mencapai rata-rata $7 \%$ per tahun itu tiba-tiba anjlok secara spektakuler menjadi minus $15 \%$ di tahun 1998, atau terjun sebesar $22 \%$. Inflasi yang terjadi sebesar 78\%, jumlah PHK meningkat, penurunan daya beli dan kebangkrutan sebagian besar konglomerat dan dunia usaha telah mewarnai krisis tersebut. Indonesia telah berada pada ambang kehancuran ekonomi, hampir semua sektor ekonomi mengalami pertumbuhan negatif. Sektor konstruksi merupakan sektor yang mengalami pertumbuhan negatif paling besar, yaitu minus 40\% karena di akibatkan tingkat bunga yang sangat tinggi, penurunan daya beli, dan beban hutang yang sangat besar. Sektor perdagangan dan jasa mengalami kontraksi minus $21 \%$, sektor industri manufaktur menurun sebesar 19\%. Semua berakibat dari implikasi krisis moneter yang mengguncang Indonesia.

Kondisi terparah ditunjukkan oleh sektor perbankan, yang merupakan penyumbang dari krisis moneter di Indonesia. Banyak bank-bank konvensional yang tidak mampu membayar tingkat suku bunga, hal ini berakibat atas terjadinya kredit macet, dan non-performing loan perbankan Indonesia telah mencapai 70\%. Akibat dari hal tersebut, dari bulan juli 1997 sampai dengan 13 Maret 1999, pemerintah telah menutup sebanyak 55 bank, di samping mengambil alih 11 bank (BTO) dan 9 bank lainnya di bantu untuk melakukan rekapitalisasi. Sedangkan bank BUMN dan BPD harus ikut direkapitalisasi.

Dari 240 bank yang ada sebelum krisis moneter, hanya tinggal 73 bank swasta yang dapat bertahan tanpa bantuan pemerintah dan dinyatakan sehat, sisanya pemerintah dengan terpaksa harus melikuidasinya. Salah satu dari 73 bank tersebut, terdapat Bank Mu'amalat Indonesia yang mampu bertahan dari terpaan krisis ekonomi, yang nyata memiliki sistem tersendiri dari bank-bank lain, yaitu dengan memberlakukan sistem operasional bank dengan sistem bagi hasil. Sistem bagi hasil yang diterapkan pada bank syariah merupakan sistem ketika pengelola dana dan penyedia dana berbagi dalam resiko dan keuntungan dengan pembagian sesuai kesepakatan. Sehingga tidak ada pihak yang dirugikan (Saputro dan Dzulkirom, 2015:1).

Pada awal pendirian Bank Muamalat, keberadaan bank syariah belum mendapat perhatian yang optimal dalam tatanan industri perbankan nasional. Landasan hukum operasi bank yang menggunakan sistem syariah ini hanya dikategorikan sebagai bank dengan sistem 
bagi hasil tanpa ada rincian landasan hukum syariah serta jenis-jenis usaha yang diperbolehkan. Hal ini juga jelas tercermin dalam UU No. 7 Tahun 1997 dimana pembahasan perbankan dengan sistem bagi hasil diuraikan hanya sepintas lalu dan merupakan sisipan belaka.

Lembaga keuangan syariah seperti Bank Muamalat adalah bank yang dalam kegiatanya harusnya sesuai dengan prinsip-prinsip syariah. Hal ini telah di tetapkan oleh Dewan Syariah Nasional. Seperti halnya pendistribusian bagi hasil pada lembaga keuangan syariah telah ditetapkan bahwa dalam pendistribusian bagi hasil dapat digunakan prinsip profit sharing maupun revenue sharing, namun Dewan Syariah Nasional lebih menekankan pada penggunaan revenue sharing. Namun pada Bank Muamalat KC Makassar seperti yang diungkap oleh bapak Anugrah Lutfi selaku Accounting Manager bahwa Bank Muamalat KC Makassar tidak mengetahui bank menggunakan prinsip profit sharing ataukah revenue sharing, alasannya bahwa Bank Muamalat pusat bagian treasury yang mengurus hal tersebut. Namun kembali ditegaskan bahwa Bank Muamalat KC Makassar akan tetap mendistribusikan bagi hasil setiap bulan kepada nasabahnya.

Sehingga ini kemudian menjadi dasar penulis untuk melakukan penelitian pada Bank Muamalat KC Makassar untuk melihat dan menganalisa prinsip pendistribusian bagi hasil apa yang digunakan oleh Bank Muamalat KC Makassar. Implikasi shariah enterprice theory kemudian akan dituangkan dalam permasalahan tersebut, untuk melihat akuntabilitas Bank Muamalat baik itu kepada stake holder tertinggi yaitu Tuhan, kemudian manusia dan alam. Karena konsep shariah enterprice theory ini bukan menepatkan manusia sebagai stakeholder tertinggi seperti pada entity theory. Kemudian prinsip pendistribusian bagi hasil ini akan dikaitkan dengan teori maslahat untuk melihat prinsip yang dapat memberikan mudharat atau kebermanfaatan, yang mendatangkan kebaikan bagi pihak-pihak yang terkait.

\section{LANDASAN TEORI}

\section{Shariah Enterprice Theory}

Shariah Enterprise Theory adalah teori yang dibangun berdasarkan metafora amanah dan metafora zakat, lebih menghendaki kesimbangan antara sifat egoistik dan altruistik dibanding dengan Enterprise Theory, teori ini diperkenalkan oleh Iwan Triyuwono melalui tulisannya. Dari beberapa diskusi telah diketahui bahwa Entity Theory lebih sarat dengan nilai-nilai kapitalisme, sehingga akuntansi syari'ah lebih cenderung pada Enterprise Theory (Triyuwono, 2007:3).Shariah Enterprise Theory menyeimbangkan nilai egoistik (materi) dengan nilai altruistik (spiritual). Shariah Enterprise Theorymemiliki cakupan akuntabilitas luas, akuntabilitas yang dimaksud adalah akuntabilitas kepada Tuhan, manusia, dan alam. Bentuk akuntabilitas semacam ini berfungsi sebagai tali pengikat agar akuntansi syari'ah selalu terhubung dengan nilai-nilai yang dapat membangkitkan kesadaran keTuhanan.

Konsekuensi menetapkan Tuhan sebagai stakeholder tertinggi adalah digunakannya sunnatullah sebagai basis bagi konstruksi akuntansi syari'ah.Intinya adalah bahwa dengan sunnatullah ini, akuntansi syari'ah hanya dibangun berdasarkan pada tata aturan atau hukumhukum Tuhan. Tuhan menjadi pusat tempat kembalinya manusia dan alam semesta, dimana manusia hanya sebagai wakil-Nya (khalifatul fil ardh) yang memiliki konsekuensi patuh terhadap semua hukum-hukum Tuhan. Oleh karena itu dengan sistem bagi hasil yang tidak maslahat dan tidak sesuai dengan prinsip-prinsip syariahmaka kesadaran ketuhanan dengan menjadikan Tuhan sebagai stakeholder tertinggi ini sangat diperlukan.

Shariah Enterprise Theorylebih menyerupai stakeholders Theory, karena kedua teori ini sama-sama mengakui keberadaan stakeholders sebagai pemegang kepentingan dan tanggungjawab perusahan. Selain itu, dalam teori tersebut mencakup nilai-nilai syariah (keadilan, rahmatan lin alamin, dan maslahah) karena dalam konsep enterprise theory dan 
stakeholders theory dijelaskan bahwa kesejahteraan tidak hanya diperuntukkan bagi pemilik modal, melainkan juga bagi kepentingan semua stakeholders (Samsiyati, 2013:48). Hal terpenting yang harus mendasari setiap penetapan shariah enterprise theory adalah Allah SWT sebagai pencipta dan pemilik tunggal dari seluruh sumberdaya yang ada di dunia ini. Dengan demikian pemilik modal maupun pengelolah modal harus saling menjaga amanah dengan mengingat bahwa segala tindakan akan diminta pertanggungjawabannya.

Akuntansi syariah melihat bahwa akuntansi bisa benar-benar berfungsi sebagai alat "penghubung" antara stockholders, entity dan publik dengan tetap berpegangan pada nilai-nilai akuntansi dan ibadah syari'ah. Kondisi ini menunjukkan bahwa akuntansi syari'ah memberikan informasi akuntansi sesuai dengan kondisi riil, tanpa ada rekayasa dari semua pihak, sebagai bentuk ibadah kepada Allah, sehingga akan tercipta hubungan yang baik antara stockholders, para akuntan, dan hubungan sosial antar manusia yang lebih baik.

\section{Maslahah Theory}

Teori maslahah pertama kali dicetuskan oleh Imam Al-Ghazzali (1111). Dusuki dan Abdullah (2007) mengungkapkan bahwa Al-Ghazali menggunakan istilah (seeking the better rule for the public good) untuk mendefinisikan maslabah sebagai keinginan untuk memperoleh manfaat dan menyingkirkan kerugian dan hal tersebut mewakili tujuan manusia yang ingin mencapai kesejahteraan. Sejalan dengan hal tersebut Zain dkk. (2014:229) menyatakan bahwa maslahah adalah perangkat hukum yang digunakan dalam teori hukum Islam untuk mempromosikan kepentingan publik dan mencegah kejahatan sosial atau korupsi. Maslahah adalah perangkat hukum yang digunakan dalam teori hukum Islam yang berfokus pada kesejahteraan, kepentingan atau manfaat kepada masyarakat, dan memukul mundur kerusakan (jalb al-masalih wa dar'u al-mafasid) (Arsad dkk., 2015:240). Oleh karena itu berdasarkan pemaparan tersebut, teori maslabah meliputi aturan hukum islam dimana dalam melakukan aktivitas yang berhubungan dengan kepentingan publik maka hal yang diutamakan adalah menciptakan kesejahteraan bukan membuat kerusakan.

Al Shatibi mengklasifikasikan pencapaian maslahah dalam tiga kategori: daruriyat (yang penting), bajiyat (komplementer), dan tabsiniyat (hiasan). Daruriyyat merupakan dasar kebutuhan utama yang harus ada dalam hidup manusia yang meliputi faith (iman), life (kehidupan), intellect (akal), posterity (keturunan), dan wealth (harta). Menurut Mohammad dan Shahwan (2013:78) apabila tingkat kebutuhan ini tidak terpenuhi maka keselamatan umat manusia baik di dunia maupun di akhirat akan terancam. Hajizat ialah kebutuhan-kebutuhan sekunder, dimana bila tidak diiwujudkan tidak sampai mengancam keselamatan, namun manusia akan mengalami kesulitan. Sedangkan tabsiniyat diartikan Al Shatibi sebagai kepentingan yang berfungsi untuk menyempurnakan kepentingan pada level sebelumnya. Ketiga tingkatan tersebut harus dipenuhi oleh manusia untuk mencapai kesejahteraan dengan mengutamakan kebutuhan daruriyat sebagai yang utama.

Maslahah disebut sebagai manfaat atau manafi' yang berarti kebaikan yang terkait dengan materi, fisik, dan psikologis. Sedangkan esensi maslahahdalam kegiatan ekonomi adalah tercapainya kesejahteraan manusia, yang terletak dalam perlindungan lima hal, yaitu agama, jiwa, intelektual, keturunan, dan harta (Falikhatun dkk., 2015:270). Oleh karena itu dalam aktivitas bisnis tujuan utama perusahaan bukan lagi didasarkan pada mencari keuntungan semata namun juga mewujudkan tercapainya kesejahteraan manusia untuk mencapai kebahagiaan dunia dan akhirat.

\section{Bank Syariah}

Bank syariah adalah lembaga keuangan yang usaha pokoknya memberikan pembiayaan dan jasa-jasa lainnya dalam lalu lintas pembayaran serta peredaran uang yang pengoperasiannyadisesuaikan dengan prinsip syariah (Muhammad, 2002:1). Perbankan syariah 
adalah suatu sistemyang dikembangkan berdasarkan prinsip syariah atau hukum syariah. Alasan pembentukan sistem ini adalah karena adanya larangan dalam agama islam untuk memungut maupun meminjam dengan bunga atau yang disebut dengan riba. Alasan kedua yaitu karena adanya larangan investasi untuk usaha-usaha yang dikategorikan haram.

Sebagaimana dijelaskan dalam Handbook of Islamic Banking, perbankan Islam menyediakan fasilitas keuangan dengan cara mengupayakan instrumen-instrumen keuangan (Finansial Instrumen) yang sesuai dengan syariah Islam. Dimensi kesejahteraan sosial dapat dikenal pada suatu pembiayaan bank. Pembiayaan bank Islam harus disediakan untuk meningkatkan kesempatan kerja dan kesejahteraan ekonomi sesuai dengan nilai-nilai Islam (Naranpanawa, 2012: 27).

\section{Bagi Haasil}

Bagi hasil dalam sistem perbankan syariah merupakan ciri khusus yang ditawarkan kepada masyarakat dan di dalam aturan syariah yang berkaitan dengan pembagian hasil usaha harus ditentukan terlebih dahulu pada awal terjadinya kontrak (akad). Besarnya penentuan porsi bagi hasil antara kedua bela pihak ditentukan sesuai kesepakatan bersama dan harus terjadi dengan adanya kerelaan (An-Tarodhin) di masing-masing pihak tanpa adanya unsur paksaan (Putri, 2012:16).Defenisi lain dari bagi hasil adalah suatu cara pembagian hasil usaha antara penyedia dana dan pengelola dana. Pembagian hasil usaha ini dapat terjadi antara bank dengan penyimpan dana maupun antara bank dengan nasabah penerima dana. Mekanisme perhitungan bagi hasil yang diterapkan di dalam perbankan syariah terdiri dari dua sistem, yaitu

\section{a. Profit Sharing (Bagi Laba)}

Bagi laba (Profit Sharing) adalah bagi hasil yang dihitung dari pendapatan setelah dikurangi biaya pengelolaan dana. Dalam sistem syariah pola ini dapat digunakan untuk keperluan distribusi hasil usaha lembaga keuangan syariah (Hardiwinoto, 2011:48). Jadi profit sharing merupakan perhitungan bagi hasil yang didasarkan kepada hasil bersih dari total pendapatan setelah dikurangi dengan biaya-biaya yang dikeluarkan untuk memperoleh pendapatan tersebut. Pada perbankan syariah istilah yang sering dipakai adalah profit andlost sharing, dimana hal ini dapat diartikan sebagai pembagian antara untung dan rugi dari pendapatan yang diterima atas hasil usaha yang telah dilakukan.

Sistem profit and lost sharing dalam pelaksanaannya merupakan bentuk dari perjanjian antara pemodal (investor) atau pengelola modal (entrepreneur) dalam menjalankan kegiatan usaha ekonomi, dimana di antara keduanya akan terikat kontrak bahwa di dalam usaha tersebut jika mendapatkan keuntungan akan dibagi antara kedua bela pihak sesuai nisbah kesepakatan di awal perjanjian. begitu pula apabila usaha mengalami kerugian akan di tanggung bersama sesuai porsi masing-masing. Kerugian bagi pemodal tidak mendapatkan kembali modal investasinya secara utuh ataupun keseluruhan sedangkan bagi pengelola modal tidak mendapatkan upah/hasil dari jerih payahnya atas kerja yang telah dilakukannya (Putri, 2012:17).

Keuntungan yang dapat didapat dari hasil usaha tersebut akan dilakukan pembagian setelah dilakukan perhitungan terlebih dahulu atas biaya-biaya yang telah dikeluarkan selama proses usaha. Keuntungan usaha dalam dunia bisnis bisa negative artinya usaha merugi, positif berarti ada angka lebih sisa dari pendapatan dikurang biaya-biaya dan nol artinya antara pendapatan dan biaya menjadi balance. Keuntungan yang dibagikan adalah keuntungan bersih (net profit) yang merupakan kelebihan dari selisih atas pengurangan total cost terhadap total revenue (Dariah, 2015:229).

b. Revenue Sharing

Revenue pada perbankan syariah adalah hasil yang diterima oleh bankdari penyaluran dana (investasi) kedalam bentuk aktiva produktif, yaitu penempatan dana pada pihak lain. Hal 
ini merupakan selisih atau angka lebih dari aktiva produktif dengan hasil penerimaan bank. Perbankan syariah memperkenalkan sistem pada masyarakat dengan istilah Revenue Sharing yaitu sistem bagi hasil yang dihitung dari total pendapatan pengelolaan dana tanpa dikurangi dengan biaya pengelolaan dana.

Adapun pengertian lain dari revenue sharing dalam arti perbankan adalah perhitungan bagi hasil didasarkan kepada total seluruh pendapatan yang diterima sebelum dikurangi dengan biaya-biaya yang telah dikeluarkan untuk memperoleh pendapatan tersebut.Sistem revenue sharing berlaku pada pendapatan bank yang akan dibagikan dihitung berdasarkan pendapatan kotor (gross sales) yang digunakan dalam menghitung bagi hasil untuk produk pendanaan bank.

\section{Akad Bagi Hasil}

a. Musyarakah (Join Venture Profit and Loss Sharing)

Musyarakah adalah akad kerjasama antara dua pihak atau lebih untuk suatu usaha tertentu di mana masing-masing pihak memberikan konstribusi dana (amal/expertise) dengan kesepakatan bahwa keuntungan dan resiko akan ditanggung bersama sesuai dengan kesepakan.Musyarakah dapat berupa musyarakah permanen dan musyarakah menurun (musyarakah muttanaqisab). Pada umumnya pembiayaan musyarakah yang diberikan oleh bank dalam bentuk kas yang dilakukan secara bertahap atau sekaligus. Adapun keuntungan atau pendapatan pada pembiayaan musyarakah dibagi diantara mitra berdasarkan nisbah yang telah disepakati. Sedangkan kerugian pembiayaan ini dibagi diantara mitra secara proposional dengan modal yang disetor.

Adapun mengenai pengakuan penghasilan usaha musyarakah dalam praktik dapat diketahui berdasarkan laporan bagi hasil atau penghasilan usaha dari mitra aktif (pengelolah usaha). Dalam pembiayaan musyarakah tidak diperkenankan mengakui pendapatan dari proyeksi hasil usaha. Dalam pembiayaan musyarakah setiap mitra tidak dapat menjamin modal mitra lain, namun setiap mitra dapat meminta mitra lain untuk menyediakan jaminan atas kelalaian atau kesalahan yang disengaja.

b. Mudharabah (Trustee Profit Sharing)

Mudharabah adalah suatu pernyataan yang mengandung pengertian bahwa seseorang memberika modal niaga kepada orang lain agar modal tersebut diniagakan dengan perjanjian keuntungannya akan dibagi antara kedua belapihak sesuai perjanjian, sedangkan kerugian ditanggung oleh pemilik modal

\section{Tabungan Mudharabah}

Tabungan mudharabah adalah tabungan yang dijalankan berdasarkan akad mudharabah. Mudharabah mempunyai dua bentuk yakni mudharabah mutlaqohdan mudharabah muqayyadah. Bank syariah bertindak sebagai mudharibdan nasabah sebagai shabibul maal. Bank syariah dalam kapasitasnya sebagai mudharib, mempunyai kuasa untuk melakukan berbagai macam usaha yang tidak bertentangan dengan prinsip syariah serta mengembangkannya, termasuk melakukan akad mudharabahdengan pihak lain. Bank syariah juga memiliki sifat sebagai seorang wali amanah, yang berarti bank harus berhatihati atau bijaksana serta beritikad baik dan bertanggung jawab atas segala sesuatu yang timbul akibat kesalahan atau kelalaiannya. Dalam mengelola dana tersebut, bank tidak bertanggung jawab terhadap kerugian yang bukan disebabkan kelalaiannya. Namun apabila yang terjadi adalah miss management, bank bertanggung jawab penuh terhadap kerugian tersebut.

\section{Deposito Mudharabah}

Fatwa DSN No. 03/DSN-MUI/IV/2000 menetapkan tentang deposito(Firdaus, 2005:28). Deposito Mudharabah merupakan simpanan berjangka dengan akad mudharabah dimana pemilik dana (shahibul maal) mempercayakan dananya oleh bank untuk dikelola atau 
bertindak sebagai mudharib dengan bagi hasil sesuai dengan nisbah yang disepakati sejak awal. Jangka waktu penarikannya ada yang 1 bulan, 3 bulan, 6 bulan dan ada yang 12 bulan serta dapat diperpanjang otomatis.Secara teknis deposito Mudharabahadalah akad kerjasama usaha antar dua pihak dimana nasabah bertindak sebagai shabibul maal(pemilik modal), sedangkan bank bertindak sebagai mudharib(pengelola). Keuntungan usaha secara mudharabah dibagi menurut kesepakatan yang dituangkan dalam kontrak, sedangkan apabila rugi ditanggung oleh pemilik modal selama kerugian itu bukan akibat kelalaian pengelola. Seandainya kerugian itu diakibatkan karena kecurangan atau kelalaian pengelola, maka pengelola harus bertanggung jawab atas kerugian tersebut.

\section{METODE PENELITIAN}

Jenis penelitian yang digunakan adalah field reseach, yaitu penelitian yang sumber datanya diperoleh dengan mendatangi perusahaan secara langsung sebagai objek penelitian. Sedangkan jenis data yang digunakan dalam penelitian adalah data kualitatif. Data kualitatif adalah memaparkan data dan memberikan gambaran penjelasan secara teoritik yang didasarkan pada masalah yang diteliti yang ada di lapangan serta mengeksplorasikan ke dalam bentuk laporan. Penelitian kualitatif seringkali merujuk pada penggunaan data kualitatif seperti hasil wawancara, observasi dan dokumentasi yang dianalisis melalui sang peneliti sebagai alat penelitian. Penelitian ini dilakukan di PT Bank Muamalat Kantor Cabang Utama Makassar. Pendekatan yang dilakukan dalam penelitian ini yaitu dengan menggunakan analisis deskriptif. Analisis deskriptif adalah metode kepenulisan yang digunakan untuk membahas suatu permasalahan dengan cara meneliti, mengolah data, menginterpretasikan hal yang ditulis dengan pembahasan yang teratur dan sistematis, ditutup dengan kesimpulan dan pemberian saran sesuai kebutuhan.

Jenis data yang digunakan dalam penelitian ini adalah data primer dan data sekunder. Data primer merupakan sumber data yang diperoleh secara langsung dari sumber asli atau pihak pertama. Data primer secara khusus dikumpulkan oleh peneliti untuk menjawab pertanyaan riset atau penelitian. Data primer dapat berupa pendapat subject riset (orang) baik secara individu maupun kelompok, hasil observasi terhadap suatu benda (fisik), kejadian ataukegiatan dan hasil pengujian. Data primer ini lebih mengacu pada informasi yang diperoleh langsung dari pengamatan objek yang diteliti.

Teknik pengumpulan data yang digunakan dalam penelitian ini adalah studi lapangan yaitu dengan melakukan survey (wawancara dengan menggunakan alat perekam) terhadap suatu objek secara langsung sebagai informan penelitian. Dokumen dalam penelitian ini berupa kata-kata dan gambar yang mampu mempercepat proses penelitian.Instrumen penelitian yang digunakan berupa alat penunjang yang dapat mengukur atau pun menggambarkan fenomena yang diamati. Adapun alat-alat penelitian yang digunakan peneliti dalam melakukan penelitian kamera, laptop, handphone, flashdisk dan alat tulis dan daftar pertanyaan dalam melakukan waawancara dengan informan. Selain itu juga, penelitian ini dilakukan dengan mengunduh (download) data yang dibutuhkan berupa annual report dan sustainability reporting.

Dalam penelitian ini analisis data yang dilakukan berdasarkan kepada jenis data yang diperoleh selama penelitian. Untuk jenis data yang diperoleh berdasarkan observasi dan wawancara yang akan dikembangkan. Proses analisis data dari hasil observasi dan wawancara ini dilakukan secara terus menerus selama proses penelitian berlangsung. Dalam penelitian ini pengujian keabsahan data hanya digunakan dalam satu uji yang paling sesuai, yaitu validasi internal (kredibilitas). 
Wika Ramdhani, et al. Penerapan Prinsip Profit Sharing...

Uji validasi internal (kredibilitas) data adalah uji kebenaran data. Ada 4 macam triangulasi sebagai teknik pemeriksaan untuk mencapai keabsahan data. Namun pada penelitia ini hanya menggunakan 2 macam triangulasi yaitu Triangulasi data dan triangulasi teori.

\section{HASIL DAN PEMBAHASAN}

\section{Penerapan Sistem Bagi Hasil Program Tabungan Mudharabah Pada PT Bank Muamalat KC Makassar}

Mudharabah muthlaqah memberikan kewenangan penuh kepada pihak lainnya (mudharib) dalam menentukan jenis dan tempat investasi sedangkan keuntungan dan kerugian dibagi menurut kesepakatan bersama.untuk penyaluran dana mudharabah mutlaqah di sebutkan oleh Oktavia Mutmainnah selaku Buisness Development Manager Funding and Wealth Management bahwa:

"Kalau mengenai penyaluran dana untuk usaha pihak ketiga itu walaupun dalam akad mudharabah muthlaqah tidak ada pembatasan atas usaha pihak ketiga tapi kami di Bank Muamalat tetap ada pembatasan yaitu hanya pada usaha-usaha yang tidak mengandung gharar dan ketidakjelasan".

Bagi hasil tabungan di bank muamalat dipengaruhi oleh beberapa faktor seperti yang diungkap oleh Oktavia Mutmainnahbahwa :

"Adapun faktor yang mempengaruhi bagi hasil tabungan adalah kurangnya hasil keuntungan dari pembiayaan yang disalurkan Bank Muamalat kepada nasabah HI-1000 kantor. Selain itu faktor yang juga mempengaruhi adalah jumlah saldo nasabah yang ditabung di Bank Muamalat dan adanya pembiayaan yang bermasalah".

Terkait penentuan nisbah program tabungan diungkap oleh Oktavia Mutmainnamengungkap bahwa :

"Untuk penentuan besarnya porsentase nisbah tabungan antara nasabah dan bank sudah ditentukan diawal sesuai dengan jenis produk tabungan yang akan dipilih nasabah dan penentuan nisabah ini berdasarkan pada keputusan dewan syariah nasional dan rapat ALCO”.

OktaviaMutmainnah kembali menjelaskan bahwa :

"Nisbah yang ditetapkan untuk semua bank syariah adalah sebesar 99 : 1. Jadi bank sebagai pengelolah dana mendapatkan nisbah bagi hasil sebesar 99 dan nasabah sebagai pemilik dana mendapat 1 (single rate). Tapi kalau untuk program Tabungan iB prima itu ada jenjang-jenjang dalam pembagian nisbah nya tergantung penempatan saldo rata-ratanya di bank maka nisbah untuk nasabah semakin tinggi. Ketika saldo nasabah dibawah Rp 100.000.0000 tetap nisbahnya 99:1, sedangkan Rp. 100.000.000 Rp. 500.000.000 ada tambahan nisbah sebesar 24 sehingga nisbah keseluruhan nasabah mendapat 25 untuk nisbah nya. Tapi sebenarnya nisbah di bank syariah itu harusnya single rate akan tetapi kelebihan dari single rate itu di klasifikasikan sebagai bonus untuk nasabah dan semakin besar saldo nasabah maka nisbah yang di dapat nasabah juga semakin besar." 
Sebagai seorang nasabah, Saiful Muchlis mengungkapkan adanya oerubahan terkait nisbah yang berlaku secara nasional. Hal tersebut terlihat dari penjelasannya bahwa :

"Awalnya saya membuka rekening di Bank Muamalat Cabang Malang dengan porsi nisbah 40:60 dimana saya sebagai nasabah mendapatkan 40 dan bank sebagai pengelolah mendapatkan 60.Dan suatu kejadian dimana saya kehilangan buku rekening sehingga saya kembali membuat ulang buku rekening saya di Bank Muamalat Cabang Makassar, namun setelah membuat ulang di Cab.Makassar, porsi nisbahnya berubah menjadi 49:51".

"Setelah dikonfirmasi pada pihak bank, alasan kenapa nisbahnya berubah menjadi 49:51 adalah ketentuan yang berlaku nasional".

"Ketika itu memang aturan nasional berarti harusnya berlaku dimana saja, baik itu di Bank Muamalat KC Malang maupun Bank Muamalat KC Makassar"

Peneliti pernahmelakukankonfirmasi ulang ke pihak bank Muamalat Cabang Makassar, Oktavia Mutmainnah mengungkap bahwa :

"Nisbah itu ditentukan pada saat pembukaan, bisa jadi waktu di Malang bisa dapat 60 pas sudah jatuh tempo dan setelah buka di Makassar perjanjiannya menjadi dapat 51, nisbah bagi hasil memang bisa berubah-berubah sesuai kesepakatan di awal pembukuan"

Berdasarkan Fatwah Dewan Syariah Nasional (DSN) No.15/DSN-MUI/IX/2000, ada dua jenis pendekatan dalam perhitungan bagi hasil atau prinsip pembagian hasil usaha yaitu profit or loss sharing dan revenue sharing termasuk pada Bank Muamalat KC Makassar. Dari dua jenis prinsip pembagian hasil usaha, pada dasarnya lembaga keuangan syariah (LKS) dapat menggunakan prinsip revenue sharing ataupun profit sharing.Akan tetapi, dilihat dari sisi kemaslahatan kedepannya (baik untuk nasabah ataupun pihak LKS) maka pembagian bagi hasil usaha sebaiknya menggunakan sistem revenue sharing.Selanjutnya terdapat faktor yang mempengaruhi tingkat bagi hasil tabungan seperti yang diungkap kembali oleh Oktavia Mutmainna bahwa :

"Adapun faktor yang mempengaruhi bagi hasil dalam produk tabungan yaitu kurangnya hasil keuntungan dari keuntungan yang disalurkan oleh Bank Muamalat kepada Nasabah, H-1000 kantor, jumlah saldo yang ditabung nasabah dank arena adanya pembiayaan bermasalah"

Berikut formula untuk pendistribusian bagi hasil produk tabungan mudharabah seperti yang disebutkanOktavia Mutmainna bahwa :

"Dalam menghitung berapa besar bagi hasil untuk shahibul mall dan mudharib pertama harus dilakukan perhitungan saldo rata-rata harian dengan formula sbb:

$$
\text { saldo rata }- \text { rata harian }=\frac{\text { saldo hari ini }}{\text { jumlah bulan berjalan }} \times \text { jumlah hari mengendap }
$$

Diasumsikan untuk contoh perhitungan saldo rata-rata harian yaitu :Tuan amir adalah nasabah Bank Muamalat berupa tabungan mudharabah. Adapun catatan kartu tabungan yang menunjukkan transaksi sebagai berikut : 
Wika Ramdhani, et al. Penerapan Prinsip Profit Sharing...

Tabel 4.3 Catatan Kartu Tabungan

\begin{tabular}{cccc}
\hline Tanggal & Debit & Kredit & Saldo \\
\hline $26 / 05 / 10$ & - & 575.000 & 575.000 \\
$02 / 06 / 10$ & 125.000 & - & 450.000 \\
$10 / 06 / 10$ & - & 250.000 & 700.000 \\
$15 / 06 / 10$ & 100.000 & & 600.000 \\
$21 / 06 / 10$ & - & $400.00-0$ & 1.000 .000 \\
\hline
\end{tabular}

Sumber : Hasil Olah Data, Tahun 2017

Menghitung saldo rata-rata harian perbulan pada tanggal 25 juli 2017 sbb:

1. Tgl. $26 / 05 / 10 \mathrm{~s} / \mathrm{d} 01 / 06 / 10=6$ hari $\times 575.000=3.450 .000$

2. Tgl. $02 / 06 / 10 \mathrm{~s} / \mathrm{d} 09 / 06 / 10=8$ hari $\mathrm{x} 450.000=3.600 .000$

3. Tgl. $10 / 06 / 10 \mathrm{~s} / \mathrm{d} 14 / 06 / 10=5$ hari $\times 700.000=3.700 .000$

4. Tgl. $15 / 06 / 10 \mathrm{~s} / \mathrm{d} 20 / 06 / 10=6$ hari $\times 600.000=3.600 .000$

5. Tgl. $21 / 06 / 10 \mathrm{~s} / \mathrm{d} 25 / 06 / 10=5$ hari $\times 1.000 .000=5.000 .000$

$$
30 \text { hari } \quad 19.150 .000
$$

Saldo Rata-Rata Harian $=\frac{19.150 .000}{30}=638.333$

Mengenai HI-1000 adalah metode untuk menghitung bagi hasil investor dari penempatan dana yang dilakukan setiap seribu rupiah yang diperoleh dari hasil penyaluran pembiayaan. Besarnya HI-1000 setiap bulannya akan berubah-ubah tergantung dari keuntungan yang Bank Muamalat dapatkan. Berikut formula untuk pendistribusian bagi hasil produk tabungan mudharabah seperti yang disebutkan Oktavia Mutmainna bahwa :

"untuk besarnya HI-1000 yang dibagikan ke nasabah itu berubah-ubah sesuai dengan pendapatan yang diterimah oleh bank muamalat dari penyaluran dana pihak ketiga"

Sedangkan rumus untuk menghitung bagi hasil tabungan bank muamalat yaitu :

$$
\text { Bagi Hasil }=\frac{\text { Saldo Rata }- \text { Rata Nasabah }}{1000} \times \mathrm{HI}-1000 \times \frac{\text { Nisbah Nasabah }}{100}
$$

Ada perhitungan bagi hasil pola baru dimana pola baru ini memiliki kelebihan yaitu penyertaan dana shohibul mall dalam investasi dikoreksi dengan GMW, bobot dihilangkan atau diseragamkan $=1$, cara perhitungan relative lebih murah, mempermudah perencanaan dan penggunaan ekuivalent rate hasil investasi per-1000 dana nasabah. Selanjutnya contoh perhitungan bagi hasil pola baru yaitu :

Diasumsikan apabilla bank muamalat mampu mengumpulkan dana pihak ketiga (DPK) sebanyak Rp 90.000.000. DPK yang disalurkan pada pembiayaan sebanyak Rp 85.500.000 (karena ada giro wajib minimum sebesar 5\%). Pembiayaan yang harus disalurkan ke masyarakat sebanyak Rp 100.000.000 diperoleh pendapatan dari penyaluran pembiayaan sebesar Rp 6.000.000. nisbah bagi hasil 65\% (nasabah): 35\% (bank). Saldo rata-rata harian nasabah (Pak Amir) sebesar Rp 1.000.000.

Tabel 4.4 Uraian DPK

\begin{tabular}{llc}
\hline Dana Pihak Ketiga (DPK) & A & 90.000 .000 \\
DPK yang disalurkan untuk pembiayaan (DPK Mudharabah) & B & 85.500 .000 \\
Pembiayaan yang Disalurkan & C & 100.000 .000 \\
Dana Bank & & 14.500 .000 \\
Pendapatan dari penyaluran pembiayaan & D & 6.000 .000 \\
Pendapatan bagi hasil setiap Rp 1000 DPK & E & 57 \\
\hline
\end{tabular}

Sumber : Hasil Olah Data, Tahun 2017 
AL-MASHRAFIYAH: Jurnal Ekonomi, Keuangan dan Perbankan Syariah Volume 2, Nomor 1 April 2018

Untuk menghitung pendapatan bagi hasil setiap Rp 1000 DPK yaitu :

$$
\mathrm{E}=\mathrm{B} / \mathrm{C} \times \mathrm{D} \times 1 / \mathrm{A} \times 1000
$$

Sehingga, $\mathrm{E}=85.500 .000 / 100.000 .000 \times 6.000 .000 \times 1 / 90.000 .000 \times 1.000=57$

Selanjutnya pendapatan dari penyaluran pembiayaan untuk pehitungan bagi hasil ke nasabah adalah merupakan pendapatan bank yang telah dikurangi biaya-biaya yang dikeluarkan oleh pengelolah bank. Seperti yang diungkap oleh Oktavia Mutmainna sebagai Business Development Manager Fundingbahwa :

"Untuk pendapatan dari penyaluran dana pihak ketiga yang dibagikan ke nasabah adalah pendapatan bersih yang sudah di dikurangi dengan biaya yang di keluarkan. Jadi biayabiaya yang dikeluarkan untuk mendapatkan pendapatan yang akan di bagikan ke nasabah tersebut sudah dikurangi dengan biaya yang dikeluarkan".

Jadi untuk perhitungan besarnya bagi hasil yaitu :

$$
\begin{aligned}
\text { Bagi Hasil } & =\frac{\text { Saldo Rata }- \text { Rata Nasabah }}{1000} \times \text { HI }-1000 \times \frac{\text { Nisbah Nasabah }}{100} \\
\text { Bagi Hasil } & =\frac{1.000 .000}{1000} \times 57 \times \frac{65}{100} \\
\text { Bagi Hasil } & =57.000 .000 \times 0.65 \\
\text { Bagi Hasil } & =37,050
\end{aligned}
$$

Dari hasil perhitungan di atas, ditemukan pendapatan nasabah untuk bulan ini dengan dananya sebesar Rp 1.000.000, bagi hasilnya sebesar Rp 37.050.

\section{Penerapan Sistem Bagi Hasil Program Deposito Mudharabah Pada PT Bank Muamalat KC Makassar}

Tahun 2016 memberikan berbagai tantangan sehubungan dengan beberapa perkembangan yang kurang menguntungkan dalam perekonomian dan pasar perbankan Indonesia, yang kemudian berimbas pada kinerja Bank Muamalat Indonesia. PT Bank Muamalat telah mengeluarkan produk tabungan deposito yang menggunakan akad mudharabah yaitu Deposito Mudharabah iB Muamalat yaitu deposito syariah dalam mata uang rupiah dan US Dollar yang fleksibel dan memberikan hasil investasi yang optimal bagi nasabah. Ketika nasabah mengambil jangka waktu 3 bulan maka nisabah yang di bagi kepada nasabah dan bank 49:51. Seperti yang ungkap oleh Oktavia Mutmainnahbahwa :

"Semakin lama jangka waktu deposito maka semakin besar nisbah bagi hasil yang diterimah oleh nasabah karena kita menggunakan akad bagi hasil”.

Selanjutnya kembali dijelaskan oleh Oktavia Mutmainnah mengenai pendapatan bagi hasil deposito di Bank Muamalat bahwa :

"Pendapatan yang dibagikan ke nasabah adalah pendapatan bersih, untuk pajak tetap dibayarkan ke Negara namun yang menanggung pajak itu adalah Bank Muamalat".

Untuk perhitungan nisbah Bank Muamalat menggunakan rumus HI-1000. Dimana penetapan bagi hasil Bank Muamalat dilakukan dengan terlebih dahulu menghitung HI-1000 yakni angka yang menunjukkan hasil investasi yang diperoleh dari penyaluran dana setiap Rp 1.000 dana nasabah. Sebagai contoh diasumsikan HI-1000 bulan januari 2009 adalah 9,99. Hal tersebut berarti bahwa dari setiap Rp 1000 dana nasabah yang dikelolah Bank Muamalat akan 
menghasilkan Rp 9,99 (HI-1000 sebelum bagi hasil). Apabila nisbah bagi hasil antara nasabah dan bank muamalat untuk deposito 1 bulan adalah 50:50 maka dari Rp 9,99 tersebut, untuk porsi nasabah dikalikan dahulu dengan 50\% sehingga untuk Rp 1000 dana yang dimiliki, nasabah akan memperoleh bagi hasil sebesar Rp 4,99 (berarti HI-1000 nasabah = 4,99 rupiah). Secara umum hal tersebut dirumuskan sebagai berikut :

$$
\text { Bagi Hasil }=\frac{\text { Saldo Rata }- \text { Rata Nasabah }}{1000} \times \text { HI }-1000 \times \frac{\text { Nisbah Nasabah }}{100} \times \text { Jangka Waktu }
$$

Diasumsikan Pak Slamet adalah seorang nasabah di bank Muamalat yang mengambil deposito mudharabah pada bulan juni senilai Rp 10.000.000 dengan jangka waktu 1 bulan. Diketahui nisbah deposito 1 bulan 50:50. HI-1000 untuk bulan juni 10.93. maka untuk mengetahui nilai bagi hasil yang akan di dapatkan pak slamet adalah :

$$
\begin{aligned}
& \text { Bagi Hasil }=\frac{\text { Saldo Rata }- \text { Rata Nasabah }}{1000} \times \text { HI }-1000 \times \frac{\text { Nisbah Nasabah }}{100} \times \text { Jangka Waktu } \\
& \text { Bagi Hasil }=\frac{10.000 .000}{1000} \times 10,93 \times \frac{50}{100} \times 1 \\
& \text { Bagi Hasil }=\text { Rp 54,650,- }
\end{aligned}
$$

\section{Penerapan Sistem Bagi Basil yang Diterapakan PT Bank Muamalat KC Makassar}

Pertumbuhan funding atau pendanaan PT Bank Muamalat Cabang Makassar stagnan pada tahun 2016 dengan estimasi 10-11\%. Bank Muamalat tidak menargetkan pertumbuhan yang tinggi pada tahun 2016 mengingat perekonomian yang masih melambat sehingga asumsi pertumbuhan pun tidak tinggi. Hal ini sama dengan kondisi yang terjadi pada tahun 2015 dimana bisnis secara keseluruhan tetap bertumbuh tapi tidak begitu signifikan. Funding masih didominasi penghimpun dana murah atau CASA dngan share sebesar 65\% sedangkan deposito individu sebesar 35\%. Sehingga pada tahun 2016 Bank Muamalat fokus untuk meningkatkan tabungan CASA dari berbagai produk unggulan seperti tabungan rencana baik tabungan rencana pendidikan, wisata atau tabungan rencana nikah.

Prinsip dasar dalam perbankan syariah adalah tidak menggunakan sistem bunga seperti pada bank-bank konvensional, melainkan dengan menggunakan sistem bagi hasil. Hal ini didasarkan pada prinsip agama islam bahwa bunga mengandung unsur riba yang diharamkan dalam agama Islam. Hal ini kemudian diimplikasikan dalam shariab enterprice theory dimana shariah enterprice theory ini dikembangkan berdasarkan karakteristik keseimbangan yang mengandung nilai egoistic-altruistik, material-spiritual, individu-jama'ah. Konsekuensi dari nilai keseimbangan ini menyebabkan shariah enterprice theory tidak hanya peduli pada kepentingan individu dalam hal ini pemegang saham, tetapi juga pihak-pihak lainnya. Oleh karena itu, shariah enterprice theory memiliki kepedulian yang besar terhadap stakeholder yang luas meliputi Tuhan, manusia dan alam.

Kepedulian stakeholder merupakan sisi keseimbangan kreativitas yang merupakan perwujudan akuntabilitas manusia sebagai wakil Allah di bumi (khalifatul fill ardh). Disisi lain shariah enterprice theory memiliki pertanggung jawaban dari sisi ketundukan dan kepatuhan menjalankan syariah islam yang merupakan perwujudan akuntabilitas manusia sebagai abdi Allah (Abd' Allah). Ketundukan manusia diharapkan berdampak pada terpenuhinya tujuan syariah bahwa setiap penciptaan, hasil dan distribusi kesejahteraan harus memenuhi kriteria halal, thoyib dan bebas riba. Terkait dengan kepatuhan menjalankan hukum islam merupakan tujuan dari akuntansi syariah itu sendiri seperti yang di ungkap oleh Saiful Muckhlis bahwa : 
"Tujuan akuntansi syariah adalah realisasi kecintan utama kepada Allah SWT. dengan melaksanakan akuntabilitas ketundukan dan kreativitas atas transaksi-transaksi ekonomi dalam sebuah entitas yang sesuai dengan nilai-nilai islam dan tujuan syariat".

Shariah enterprice theory menempatkan Tuhan sebagai stakeholder tertinggi, sehingga tali penghubung antara akuntansi syariah tetap bertujuan pada membangkitkan kesadaran keTuhanan para pengguna tetap terjamin. Intinya adalah bahwa dengan sunnatullah sebagai basis konstruksi akuntansi syariah ini hanya dibangun berdasarkan pada tata aturan atau hukum-hukum Tuhan. Hal inilah yang kemudian membuat masyarakat yakin dan percaya untuk memilih perbankan syariah kususnya nasabah Bank Muamalat KC Makassar untuk menyimpan dananya baik itu dalam bentuk tabungan mudharabah maupun deposito mudharabah. Seperti yang kemudian diungkap oleh Oktavia Mutmainnahbahwa :

"Masyarakat lebih mempercayakan dananya untuk dikelolah oleh Bank Muamalat karena Bank Muamalat adalah bank yang berlabel syariah sehingga bagi masyarakat yang menghendaki kepatuhan syariah merasa aman dan telah menjalankan syariat dengan memilih bank yang dalam kegiatan operasionalnya mengikuti prinsip-prinsip dan aturan syariat islam".

Hal ini kemudian menjadi akuntabilitas baik bagi pihak bank sebagai pengelolah dana maupun pihak nasabah sebagai penyedia dana pada Bank Muamalat sebagai pertanggung jawabannya terhadap kepatuhannya kepada Tuhan pemilik semesta akan tata aturan dan hukum-hukum Allah SWT.

Syariah islam berkeyakinan dalam sistem bunga terdapat unsur ketidakadilan seperti yang diterapkan pada bank konvensional, karena pemilik dana mewajibkan peminjam membayar lebih daripada yang telah dipinjamkan tanpa memperhatikan peminjam mengalami keuntungan atau kerugian. Sebaliknya sistem bagi hasil yang diterapkan pada bank syariah merupakan sistem ketika pengelola dana dan penyedia dana berbagi dalam resiko dan keuntungan dengan pembagian sesuai kesepakatan. Sehingga tidak ada pihak yang dirugikan (Saputro dan Dzulkirom, 2015:1). Terkait pembagian dalam nisbah mudharabah haruslah berdasrkan kesetaraan kesempatan dalam mendapatkan keuntungan sesuai dengan porsi masing-masing dalam bentuk kontribusi dan tanggung jawab yang dibebankan. Keadilan sebagai landasan dalam segala hal dijadikan acuan untuk melakukan tindakan atau keputusan lebih baik. Hal ini sesuai dengan firman Allah SWT surah An-Nahl ayat 90 yang terjemahnya :

"Sesungguhnya Allah menyuruh (kamu) Berlaku adil dan berbuat kebajikan, memberi kepada kaum kerabat, dan Allah melarang dari perbuatan keji, kemungkaran dan permusuhan. Dia memberi pengajaran kepadamu agar kamu dapat mengambil pelajaran".

Stakeholder yang kedua dalam shariah enterprice theory adalah manusia disini dibedakan menjadi dua kelompok yaitu direct-stakeholder dan indirect-stakeholder. i adalah pihak-pihak yang secara langsung memberikan kontribusi pada perusahaan, baik dalam bentuk kontribusi keuangan maupun non-keuangan. Karena mereka telah memberikan kontribusi kepada perusahaan, maka mereka mempunyai hak untuk mendapatkan kesejahteraann dari perusahaan. Seperti yang diungkap oleh Oktavia Mutmainnahbahwa :

"Nasabah yang telah menabung dan mendepositkan dana nya pada Bank Muamalat KC Makassar berhak mendapatkan hak untuk mendapatkan kesejateraan dari perusahaan berupa bagi hasil yang akan didistribusikan kepada nasabahnya setiap bulan sesuai dengan nisbah kesepakan di awal". 
Sementara yang dimaksud dengan indirect-stakeholder adalah pihak-pihak yang sama sekali tidak memberikan kontribusi kepada perusahaan baik itu secara keuangan maupun nonkeuangan. Akan tetapi secara syariah mereka adalah pihak yang memiliki hak untuk mendapatkan kesejateraan dari perusahaan. Hal ini berkaitan dengan adanya kebermanfaatan atau mudharat atas esensi Bank Muamalat KC Makassar dengan memberikan bantuan-bantuan kepada masyarakat yang kurang beruntung. Salah satu contohnya adalah pada tanggal 27 November 2017 Bank Muamalat dan Badan Amil Zakat telah menyalurkan beasiswa untuk ratusan anak-anak yatim di Masjid Baitussalam. Bank Muamalat melalui program CSR unggulannya yaitu sekolah prestasi muamalat, menyalurkan beasiswa pendidikan senilai lebih dari Rp 90 juta yang terdiri dari donasi tunai dan perlengkapannya. Seperti yang diungka oleh Achmad K. Permana bahwa :

"Sampai dengan saat ini apabila dilihat dari skala nasional pendidikan di Indonesia masih banyak ditemukan berbagai kendala, seperti misalnya terbatasnya memperoleh akses pendidikan, selain itu kualitas relevansi dan daya saing yang masih rendah seta ketersediaan sarana dan prasarana pendidikan yang berkualitas pun masih terbatas".

Golongan stakeholder yang terakhir dari shariah enterprice theory adalah alam. Alam adalah pihak yang memberikan kontribusi bagi mati hidupnya perusahaan sebagaimana pihak Tuhan dan manusia. Perusahaan eksis secara fisik karena didirikan diatas bumi, menggunakan energy yang tersebar di alam dan memberikan jasa kepada pihak lain dengan menggunakan energy yan tersedia dialam. Namun demikian, alam tidak menghendaki distribusi kesejahteraan dari perusahaan dalam bentuk uang sebagaimana yang diinginkan manusia. Wujud distribusi kesejahteraan berupa kepedulian terhadap kelestarian alam, pencegahan pencemaran dan menjaga kebersihan lingkungan.

Dari analisis penerapan sistem bagi hasil untuk jasa dan produk penghimpun dana pada Bank Muamalat seperti tabungan dan deposito, bank muamalat membagi pendapatan dari pendapatan bersih Bank. Sehingga hal ini sesuai dengan prinsip pendistribusian bagi hasil yaitu profit sharing. Seperti yang diungkap oleh Oktavia Mutmainna bahwa :

"Untuk pendistribusian bagi hasil di Bank Muamalat produk dan jasa penghimpun dana itu kami menggunakan sistem profit sharing jadi pendapatan yang dibagikan ke nasabah itu adalah pendapatan bersih yang di dapat Bank".

Dimana profit sharing ini merupakan sistem pendistribusian bagi hasil dengan membagi pendapatan bersih yang didapat oleh Bank dari penyaluran dana pihak ketiga. Penerapan prinsip profit sharing pada Bank Muamalat KC Makassar mendapat dukungan dari Saiful Mukhlis selaku nasabah Bank Muamalat seperti yang diungkap bahwa :

" Prinsipprofit sharing yang diterapkan oleh Bank Muamalat KC Makassar memang lebih mencerminkan keberadaan islam karena aspek keadilan lebih tercermin dalam pembagian pendapatan atas penyaluran dana kepihak ketiga baik kepada Bank sebagai pengelolah maupun kepada nasabah sebagai penyedia dana".

Pada dasarnya lembaga keuangan syariah dalam hal ini Bank Muamalat boleh menggunakan prinsip revenue sharing maupun profit sharing dalam pembagian hasil usaha dengan mitranya. Namun dewan syariah nasional lebih menekankan menggunakan prinsip revenue sharing dilihat dari segi kemaslahatannya. Bukan cuman Fatwah DSN yang mendukung di terapkannya sistem revenue sharing pada lembaga keuangan syariah, namun beberapa penelitian seperti Supono mengungkap bahwa prinsip revenue sharing lebih mudah diterapkan oleh masyarakat Indonesia. Hal ini disebabkan masyarakat Indonesia belum terbiasa untuk 
menerima bagi rugi. Ketika dilihat dari pihak penyedia dana prinsip revenue sharing memang lebih menguntungkkan dibanding dengan penerapan prinsip profit sharing.

Namun apabila dilihat dari pihak pengelolah dana dalam hal ini bank, prinsip revenue sharing kurang maslahat seperti yang diungkap oleh Oktavia Mutmainna hbahwa :

"Prinsip revenue sharing menurut saya kurang maslahat karena apabila tingkat pendapatan yang diterimah bank sedemikian rendah maka bagian bank setelah didistribusikan oleh bank, tidak akan mampu membiayai kebutuhan operasionalnya sehingga merupakan kerugian bank dan membebani para pemegang saham sebagai penanggung kerugian. Sementara para penyandang dana atau investor tidak akan pernah menanggung kerugian akibat biaya operasional tersebut".

Dengan kata lain secara tidak langsung bank menjamin nilai nominal nasabah (penyedia dana) karena pendapatan paling rendah yang akan dialami oleh bank adalah nol dan tidak mungkin terjadi pendapatan negatif. Hal ini kemudian bertentangan dengan karakteristik keseimbangan, kesejahteraan dan keadilan yang ada dalam shariah enterprice theory. Dalam aspek kesejahteraan ketika menggunakan prinsip revenue sharing maka pihak bank sebagai pengelolah dana akan menanggung sendiri biaya yang dikeluarkan sementara pendapatan yang dibagikan kepada penyedia dana adalah pendapatan diluar biaya yang dikeluarkan sehingga kesejahteraan bagi pengelolah dana tidak akan tercapai. Hal ini juga bertentangan denganteori maslahat dimana dalam teori masalahat ini berarti kebaikan yang terkait dengan materi, fisik, psikologi sedangkan esensi maslahat dalam kategori ekonomi adalah tercapainya kesejahteraan manusia yang terletak dalam perlindungan lima hal yaitu agama, jiwa, intelektual, keturunan dan harta.

Sehingga Khasanah (2006:6) mengatakan bahwa prinsip profit sharing lebih maslahat daripada revenue sharing karena dengan sistem ekonomi berdasarkan profit and lost sharing akan menjamin alokasi sumber ekonomi yang lebih baik dan akan mendukung terjadinya distribusi pendapatan yang sesuai. Penelitian yang dilakukan Nabhan (2006:20) mengatakan bahwa prinsip profit sharing adalah mekanisme keuangan yang paling baik ditinjau dari aspek hukum islam sekaligus menjadi ciri keberadaan bank islam. Kemudian hal ini sesuai dengan teori maslahat dimana teori maslahat ini merupakan seperangkap hukum dengan penerapan prinsip profit sharing dalam manajemen dana bank akan meningkatkan kekuatan portofolio investasi. Hal ini disebabkan karena dengan penerapan prinsip profit sharing akan meningkatkan kemampuan bank dalam mendapatkan kepercayaan masyarakat dan memobilisasi dana mereka dengan mempertimbangkan faktor-faktor internal dan eksternal.

Prinsip profit sharing ini lebih sesuai dengan teori maslahat karena pembagian pendapatan itu di bagikan kepada shahibul mall dan mudharib adalah pendapatan bersih yang sudah dikurangi dengan biaya operasional pengelolah dana. Sehingga apabila menggunakan profit sharing kedua belah pihak yaitu penyedia dana dan penggunana dana akan mendapat keuntungan dari bagi hasil meskipun pendapatan yang didapatkan oleh pengelola dana tergoleng kecil, pendapatan tersebut akan dibagi sesuai dengan nisbah setelah pengguna dana membayar biaya-biaya dalam proses mendapatkan keuntungan tersebut. Sehingga salah satu pihak tidak akan merasakan kerugian meskipun pendapatan yang diterimah tergolong minim, hal ini sesuai dengan prinsip keadilan dan teori maslahat berkenaan dengan kesejahteraan kedua bela pihak. Dengan melalui proses pembagian hasil yang berjalan secara adil dan berprinsip syariah maka kedua bela pihak telah menjalankan syariah dengan menghindari praktek bunga yang biasa kita kenal dengan istilah riba yang jelas diharamkan dalam agama. 


\section{PENUTUP}

Kesimpulan yang diambil penulis adalah sebagai berikut :

a. Produk dan jasa penghimpun dana seperti Tabungan dan Deposito pada PT Bank Muamalat Indonesia adalah suatu simpanan dan investasi yang berdasarkan akad mudharabah muthlaqah yang tidak bertentangan dengan prinsip syariah dan penarikannya hanya dapat dilakukan menurut syarat dan ketentuan tertentu yang disepakati tetapi tidak dapat ditarik dengan cek atau bilyet giro.

b. Dalam sistem tabungan dan deposito mudharabah tingkat keuntungan yang diperoleh nasabah akan mengalami peningkatan dan penururnan tergantung kepada nisbah bagi hasil yang diperoleh. Bagi hasil di Bank Muamalat Indonesia dihitung pada akhir bulan.

c. Pendistribusian bagi hasil pada jasa dan produk penghimpun dana seperti tabungan dan deposito yang diterapkan oleh Bank Muamalat Indonesia adalah menggunakan prinsip profit sharing artinya pendapatan yang didistribusikan kepada nasabah adalah pendapatan bersih.

d. Pendistribusian bagi hasil dengan prinsip profit sharing pada Bank Muamalat Indonesia lebih sesuai dengan teori maslahat karena masing-masing pihak menanggung keuntungan dan kerugian sehingga tidak ada salah satu pihak yang merasa dirugikan dan akan mencapai kesejahteraan dan kedua bela pihak akan merasakan mudharatnya.

Adapun saran yang mungkin dapat berguna untuk perkembangan Bank Muamalat Indonesia KC Makassar dimasa yang akan datang yaitu sebagai berikut :

a. Untuk meningkatkan dan memperkenalkan Bank Muamalat Indonesia terutama mengenai produk-produk dan jasa penghimpun dana seperti tabungan dan deposito dengan prinsip syariah haruslah diperbanyak promosi karena masyarakat masih banyak yang belum faham betul mengenai produk-produk yang berbasis syariah dan bedanya dengan yang konvensional.

b. Menyiapkan sumber daya manusia yang professional dan yang menguasai basic syariah sehingga dapat memajukan Bank Muamalat KC Makassar dan perluhnya jaringan perbankan syariah sehingga dapat dijangkauoleh banyak kalangan masyarakat luas.

c. Secara terus menerus melakukan pembaharuan dan pelayanan yang memuaskan bagi nasabah Bank Muamalat Indonesia KC Makassar.

\section{DAFTAR PUSTAKA}

Al-Qur'an dan Terjemahnya. 2014. Jakarta: Departmen Agama RI

Awaluddin, Murtiadi, 2009. Research on Key Factors in Determining Value of Firms for Listed Manufacturing Firms at Indonesian Stock Exchange, Unpublished Dissertation Post GraduateProgram Hasanuddin University

Awaluddin, Murtiadi. "Pengaruh Kepribadian Entrepreneuship Islam Dan Akses Informasi Terhadap Strategi Bisnis Dan Kinerja Bisnis Usaha Kecil Di Kota Makassar." Jurnal Iqtisaduna 3, no. 1 (2017): 79-97.

Dariah, AR, Yuhka Sundaya dan Zaini Abdul Malik. 2015 .Optimizing Input dan Output bawah Skema Mudharabah. InternationalJournal of Sciences dan Penelitian. 4(5): 227-231.

Dariah, AR, Yuhka Sundaya dan Zaini Abdul Malik. 2014. Enriching the Theory of Factor Pricing and Income Distribution in Islamic Perspective.Journal Of Social Sciences Research. 5(3): 872-881.

Falikhatun., Sri Iswati dan Mohammad Saleh. 2015. Implementation Of Qardh On Islamic Banking Indonesia Based On Islamic Economics Theory. Jurnal Unissula. 2(1): 268-273

Hardiwinoto. 2011. Analisis Komparasi Revenew And Profit Sharing Pada Sistem Mudharabah Pada PT BPRS PNM BINAMA SEMARANG. Value Added. 7(2): 46-67. 
AL-MASHRAFIYAH: Jurnal Ekonomi, Keuangan dan Perbankan Syariah Volume 2, Nomor 1 April 2018

Muhammad, wiroso dan harahap. 2002. Akuntansi Perbankan Syariah. UPP AMK YKPN,Yogyakarta. 1.

Mohammad, Mustafa Omar dan Syahidawati Shahwan. 2013. The Objective of Islamic Economic and Islamic Banking in Light of Maqasid Al-Shariah: A Critical Review. Middle-East Journal of Scientific Research 13 (Research in Contemporary Islamic Finance and Wealth Management). 7584.

Naranpanawa. 2012. Empiris Pendapatan Distribusi: thecase dari Sri Lanka. International Journal of Economics Sosial. 40(1): $26-50$.

Putri, Gianisha Oktaria. 2012. Analisis Bagi Hasil Deposito Mudharabah Pada Bank Umum Syariah Indonesia. Skripsi. Universitas Indonesia.

Samsiyah, Yudhanta Sambharakhresna dan Nurul Kompyurini. 2013. Kajian Implementasi Corporate Responsibility Perbankan Syariah Ditinjay dari Shariah Enterprises Theory pada PT. Bank Pembiyaan Rakyat Shariah Bakti sumekar Cabang Pamekasan. Jurnal Investasi. 9(1): 47-60.

Saputro, Anan Dwi Dan Moch Dzulkirom. 2015. Sistem Perhitungan Bagi Hasil Pembiayaan Mudharabah Pada PT. Bank Syariah Mandiri Cabang Malang. Jurnal Administrasi Bisnis (JAB). 21(2): 1-6

Supono. 2010. Evaluasi Bagi Hasil Pada BPRS WAKALUMI. Jurnal Penelitian Pengembangan Ilmu Manajemen Dan Akuntansi, INOV ASI. 3. 1-32

Triyuwono, Iwan. 2007. Mengangkat Sing Liyan untuk formulasi nilai tambah Syariah. Makassar.Simposium Nasional Akuntansi X. Makassar.

Zain, Mustaffa Mohamed., Faizah Darus, Haslinda Yusoff, Azlan Amran, Hasan Fauzi, Yadi Purwanto dan Dayang Milianna Abang Naim. 2014. Corporate ibadab: an Islamic Perspective of Corporate Social Responsibility. Middle-East Journal of Scientific Research. 22(2): 225-232. 